\title{
The Skin and Gut Microbiome and Its Role in Common Dermatologic Conditions
}

\author{
Samantha R. Ellis ${ }^{1,2}$, Mimi Nguyen ${ }^{3}$, Alexandra R. Vaughn ${ }^{2}$, Manisha Notay ${ }^{2}$, \\ Waqas A. Burney ${ }^{2,4}$, Simran Sandhu ${ }^{3}$ and Raja K. Sivamani $2,4,5,6,7, *$ (D) \\ 1 PotozkinMD Skincare Center, Danville, CA 94526, USA; samantha.rose.ellis@gmail.com \\ 2 Department of Dermatology, University of California-Davis, Sacramento, CA 95816, USA; \\ missallievaughn@gmail.com (A.R.V.); mnotay@gmail.com (M.N.); \\ waqas.ahmed.burney@gmail.com (W.A.B.) \\ 3 School of Medicine, University of California-Davis, Sacramento, CA 95817, USA; \\ nguyen.mimi.ph@gmail.com (M.N.); youngsimbaa32@gmail.com (S.S.) \\ 4 Department of Biological Sciences, California State University, Sacramento, CA 95819, USA \\ 5 College of Medicine, California Northstate University, Elk Grove, CA 95757, USA \\ 6 Pacific Skin Institute, Sacramento, CA 95815, USA \\ 7 Zen Dermatology, Sacramento, CA 95819, USA \\ * Correspondence: raja.sivamani.md@gmail.com
}

Received: 16 October 2019; Accepted: 6 November 2019; Published: 11 November 2019

\begin{abstract}
Microorganisms inhabit various areas of the body, including the gut and skin, and are important in maintaining homeostasis. Changes to the normal microflora due to genetic or environmental factors can contribute to the development of various disease states. In this review, we will discuss the relationship between the gut and skin microbiome and various dermatological diseases including acne, psoriasis, rosacea, and atopic dermatitis. In addition, we will discuss the impact of treatment on the microbiome and the role of probiotics.
\end{abstract}

Keywords: gut; skin; microbiome; acne; psoriasis; rosacea; atopic dermatitis

\section{The Skin Microbiome}

Mary Marples's article, "Life on the human skin", parallels the diverse ecosystems of the skin to those of our Earth [1]. Skin is likened to soil, with the human host being the Earth on which these microcosms exist. Both environments support life and exert selective pressures on these organisms, from " ... the desert of the forearm, [to] the tropical forest of the armpit, [and] the cool woods of the scalp". The skin is much more than just its resident constituents-the skin is a rich ecosystem that supports diverse populations of organisms, and like all life, these microorganisms, too, are competing for their chance to survive. In this light, skin microbiome research can evolve beyond focusing on the analysis of skin inhabitants and instead foster a respect for the beautifully integrated portrait before us: the system and its ecology. By focusing on the interactions between the biological and ecological systems, one has the chance to appreciate this portrait of a unique environment and its equally unique residents coming together to form a dynamic ecosystem.

The skin is comprised of three major habitats: moist, sebaceous, and dry. Sebaceous skin includes the face, chest, and back, and is a comparatively simple community, composed mainly of several species of Cutibacterium (formerly Propionibacterium), Staphylococcus bacteria, and Malassezia yeasts [2-4]. Sebum excretion appears to be the primary driving force in sebaceous microbiome development and maintenance, as sebaceous microbiomes shift dramatically around puberty when oil production increases [3]. 
Dry skin sites, such as the arms and legs, are also dominated by Cutibacterium acnes and Staphylococcus species, but with additional significant portions of Gammaproteobacteria and Betaproteobacteria [5]. Moist sites have more variability, with the constantly moist toe web favoring Corynebacterium growth, while the phalangeal web, which features abundant sweat glands but is generally drier, favoring Staphylococci [5]. Invaginations of the skin (e.g., hair follicles, sebaceous glands, and sweat glands) create distinct microenvironments and oxygen gradients which may promote the growth and colonization of particular microbes. For example, Cutibacteria are oxygen tolerant anaerobes, though they grow much faster in truly anaerobic environments, while Staphylococci are facultative anaerobes and grow fastest in the presence of oxygen. It is important to note that most physiological research on Staphylococcus species has been done during aerobic growth [6-11], so the effects of hypoxic or anoxic conditions on metabolism is unknown.

It is apparent that the skin microbiome is important in homeostasis, partially through the maintenance of the cutaneous immune system. For example, some strains of S. epidermis have been found to enhance the innate barrier immunity and activate IL-17+ CD8 T cells to protect against infection [12]. In a study by Naik et al., mice raised in germ-free conditions exhibited a reduction in IL-17A production in the skin, that was reversible with subsequent S. epidermis colonization [13]. In addition, S. epidermis is found to induce CD8 T cell associated transcripts important in promoting tissue repair [14]. Although further research is needed to fully elucidate the workings of the cutaneous immune system, it is evident that residential microbes play an important role.

\section{Gut: Local and Systemic Modulation}

The human gastrointestinal tract is home to several different microbial ecosystems that colonize the entire mucosal lining $[15,16]$. This dynamic system is influenced by genetics, diet, and several other environmental factors [17]. Nearly 10 million genes have already been identified in the gut microbiome [18], many of which are used to support the human genome in performing several important and essential functions like vitamin production, immune regulation, protection from pathogens, serum lipid modulation, and metabolism of xenobiotics and food components [19-21]. The resulting metabolites may also influence metabolism within the host, demonstrating that both the human genome and gut microbiome play a role in the metabolic pathways occurring in the human body [22,23]. The catabolic end products from the fermentation of complex carbohydrates and other undigested food components by the intestinal microbes are incorporated into the body's short chain fatty acids (SCFAs). Therefore, any change in the gut microbiota's composition or metabolic activity may also alter fatty acid levels [23,24].

Fermentation of prebiotics by the gut microbiota can also produce SCFAs, which may improve the function and integrity of the gut, modulate the immune system and inflammatory response, and affect lipid and glucose metabolism [25]. In fact, these byproducts may be anti-tumorigenic, as SCFAs, butyrate, acetate, and propionate, produced by the fermentation of dietary fibers by colonic microbes, have also been shown to induce apoptosis in colorectal tumor cells [26]. There is emerging evidence that free fatty acids (FFAs), in addition to serving as an important sources of energy, are also involved in several biological processes including modulation of gene expression of adipocytes, macrophages, and endothelial cells [27-30].

FFAs can also modulate cytokine and chemokine production, gene expression of adhesion molecules, and have pro-resolution and anti-inflammatory properties, thereby controlling inflammation at multiple levels $[18,28,29,31-33]$. Javier et al. showed that increased intestinal colonization of Akkermansia was the major predictor of serum total FFA levels, and was negatively related to the total FFA and IL-6 (a proinflammatory cytokine) levels. He also found that altered serum levels of FFAs were associated with an imbalance between Lactobacillus and Akkermansia, as well as increased serum IL-6 levels, fecal SCFA, and subclinical prevalence of metabolic alterations [24].

Gut microbiota may also convert excess proteins and amino acids into certain toxins, like indoxyl sulfate, trimethylamine $\mathrm{N}$-oxide (TMAO), and p-cresyl sulfate, which may be involved in a number of 
diseases [34]. Current evidence suggests that the most effective way to improve the microbiotic profile is increasing dietary fiber, which results in an increased synthesis of SCFAs by the gut microbiome and decreased levels of certain toxic molecules [35]. In addition, supplementation with omega-3 polyunsaturated fatty acids also increases SCFA-producing bacteria [36]. Taken together, the data highlights an important relationship between human gut microbiota, its metabolism, and its related effects on overall human health.

\section{Role of Diversity in the Microbiome}

The gut and skin microbiota are made up of trillions of microbes, derived from thousands of different strains, that live together as an intricate ecological community. These microbiota, along with their metabolic byproducts and host interactions, directly influence both normal physiology and disease processes. For instance, disruption of the normal symbiotic relationship between gut microbes and the host is associated with inflammatory bowel disease (IBD) [37,38], obesity [39], and metabolic syndrome [40]. We are still trying to understand how microbial diversity in the gut and on the skin influences health, but there is evidence that increased microbial diversity overall is associated with improved physiology and homeostasis [15].

It is important to note that diversity of microbes in the intestines varies drastically across human populations and cultures and even varies significantly within healthy individuals over time [41]. The microbiome changes considerably over the first three years after birth and is highly sensitive to environmental factors such as breastfeeding and antibiotics [42]. It is generally accepted that two phyla, Bacteroidetes and Firmicutes, usually predominate in the microbiome of adults, while Actinobacteria and Proteobacteria make up a smaller portion [15]. Even so, there can still be variations in the proportions of these phyla and in the species from person to person.

Another important component that diversifies the microbiome is the diversity of functional gene profiles within the gut. Characterization of genome content through sequencing of cultured gut isolates offers important information about the functional capacity of the gut microbiome. Interestingly, one study showed that despite having very different microbial compositions in the gut, a group of 18 females shared over $93 \%$ of the same enzyme level functional groups [43]. This study demonstrated that diverse communities of bacterial phyla and strains nonetheless yield highly similar core microbiomes with similar functions. Researchers have hypothesized that increased microbial diversity in the gut confers resilience, thereby promoting health and preventing disease [44]. The term "species richness" is often used to describe the number of species present in someone's microbiome, and those with more species-rich microbial communities are less susceptible to invasion by pathogenic microbes.

The importance of microbiome diversity has recently been highlighted in research examining the associations between skin and gut microbiota and dermatologic conditions such as atopic dermatitis, acne, rosacea, and psoriasis. In general, it appears that increased diversity of the entire microbiome plays a beneficial role in promoting gut health. With skin, it is more complex. While skin microbiome diversity is important, the role of sebum can be influential to controlling diversity. In sebum-rich areas lipophilic bacteria are more dominant and drier skin may promote a more diverse microbiome. However, because increases in diversity can correlate with increased skin dryness, this may not be healthy if it implicates an impaired skin barrier.

\section{Disease-Specific Changes}

\subsection{Acne}

The acne microbiome has been studied for several decades, beginning first with culture based work in the 1960s and continuing now with sequencing surveys [1,45-48]. Perhaps in part due to its taxonomy, Cutibacterium acnes (formerly Propionibacterium acnes) was the presumed causative agent of acne vulgaris, though there is still a lack of consensus. There are at least three well-recognized sub-groups of $C$. acnes (I, II, and III), but up to nine ribotypes have been parsed [45,49-53]. The acne-associated C. acnes strains 
differ mainly in (putative) lipases, carbohydrate transport and metabolism, putative antimicrobial peptides, and putative virulence factors (CAMP and tly homologues) [54,55]. Barnard et al. also hinted that $C$. acnes bacteriophages may play a role in pathology, with phage being more prevalent and in higher abundance in control subjects, presumably controlling the abundance of $C$. acnes within the follicle [56,57].

While S. epidermidis has long been known as an opportunistic pathogen of soft tissues [58], its potential role in acne pathology has been largely ignored. This is despite several studies which show it is more abundant on acne subjects and on active lesions [59-61]. However, one study suggests that S. epidermidis may support recovery in acne lesions [62], though there appear to be some methodological shortfalls.

Malassezia species, and more recently Candida species, have also been implicated in acne pathology, causing well-documented cases of folliculitis [63-68]. However, researchers are usually careful not to call yeast-associated folliculitis "acne", due to the perception that acne vulgaris includes other clinical findings such as comedones that are not typically found in yeast-associated folliculitis.

The causes of acne are complex and are promoted by an intermicrobial interaction rather than by the mere presence of a particular microbe. Some have attempted to harness the resident microbiome to create an acne therapy by decreasing $C$. acnes colonization [69,70], but none of these technologies have successfully made it to market or proven efficacy in vivo.

There has been a distinct paucity of studies examining the microbiome before and after successful treatments, with most using healthy controls and acne subjects. Given that the mechanisms of the most prescribed acne medications, including antibiotics, are largely unknown, this could be a fruitful approach to understanding the skin microbiome and the etiology of acne.

\subsection{Atopic Dermatitis}

Atopic dermatitis (AD), often colloquially referred to as eczema, is a chronic allergic skin disease characterized by an erythematous, dry, and intensely pruritic rash in a distinctive distribution [71]. The disease burden of AD is high, as it afflicts up to $20 \%$ of infants and $3 \%$ of adults worldwide and is often associated with other diseases like allergic rhinitis and asthma [72,73]. The cause of AD is known to be multifactorial, with both genetic and epigenetic factors contributing [71]. Notably, the incidence of $\mathrm{AD}$ is much higher in industrialized countries, and has continued to increase for decades, suggesting that excessive hygiene may be affecting the body's microbial milieu and inhibiting the body from adapting beneficial immune responses to pathogens [74-77]. Numerous studies have explored the role of the skin microbiome and its effects on the clinical manifestations of AD.

In $\mathrm{AD}$, gene defects lead to both physical and Th2-mediated immunological disruptions in the skin barrier, precipitating increased susceptibility to infection and allergens [78]. This barrier dysfunction is then exacerbated by the physical stress of repeated scratching of dry, itchy skin [79]. Th2 cytokines can suppress keratinocyte induction of antimicrobial peptides (AMP) such as human beta-defensin-3 and cathelicidins, both of which prohibit colonization of pathogenic organisms such as S. aureus, thereby maintaining microbiotic homeostasis [80,81]. Over time, the skin microbial flora become altered from their usual composition, driving the skin towards a diseased state. Further contributing to our understanding that certain microbial communities play a crucial role in the manifestation of this disease, AD classically involves the antecubital and popliteal fossae-body sites that host similar compositions of specific organisms [82].

Staphylococcus aureus is consistently implicated in $\mathrm{AD}$, and has been shown to colonize lesional AD skin at high rates-much more so than nonlesional atopic skin or the skin of healthy subjects [83-86]. Furthermore, a higher density of colonization with $S$. aureus is correlated with more inflammation and increased disease severity $[84,87,88]$. However, it is not just the types of bacteria, but also the diversity of organisms, that play a role in $\mathrm{AD}$, as a lack of cutaneous microbial diversity contributes to disease pathogenesis. A study by Kong et al. demonstrated that in lesional AD skin the microbiome is dominated by staphylococcus species, particularly S. aureus, thereby decreasing the overall diversity 
of other microorganisms [4]. Another clinical investigation showed that infants colonized with S. epidermidis and S. cohnii by two months of age had a significantly reduced risk of developing eczema by one year of age, possibly due to increased microbiome diversity [89]. A 2017 study by Nakatsuji et al. demonstrated that compared to the skin of AD subjects, healthy subjects had much higher levels of coagulase-negative Staphylococcus species (specific strains of S. epidermidis and S. hominis) with anti-S. aureus activity. When isolated and introduced into human subjects with $\mathrm{AD}$, these coagulase negative strains decreased cutaneous $S$. aureus colonization [10]. Supporting these findings, a recent pediatric trial found that patients with mild AD flares had more S. epidermidis detected, while those with severe disease were colonized by dominant $S$. aureus strains [90]. These discoveries illustrate that a properly functioning skin microbiome protects against pathogenic organisms, whereas disruption in the microbiotic environment encourages atopic disease.

Though atopic dermatitis is considered a skin disorder, the gut microbiome is also thought to play a role in disease pathogenesis. Many investigations exploring this relationship are performed in infants and children, as this is the demographic with the highest disease prevalence [71]. Similar to the skin microbiome, both the presence of specific organisms and the degree of microbiotic diversity are implicated. Several prospective studies show that the colonic microbiomes of infants who develop AD later in life have lower levels of microbial diversity [91-94]. These prospective studies highlight that irregularities in gut microbiota precede manifestations of $\mathrm{AD}$ and may warrant further study to assess if there is a causative role.

Researchers have also explored the prevalence of various types of gut bacteria in patients with and without eczema. As in the skin, studies have noted higher counts of $S$. aureus in fecal samples of AD subjects $[95,96]$. Delving deeper, a recent publication found that the $S$. aureus strains in infants (0-2 months of age) who developed AD by 18 months of age were less likely to have genes encoding for a specific superantigen and elastin-binding protein [97]. It was postulated that these bacterial proteins help the infant immune system mature, thus preventing atopic disease. Aside from S. aureus, many other bacteria species have been found to be more prevalent in AD individuals. Both prospective and cross-sectional studies have found higher prevalence of clostridia species among children and adults with AD $[95,96,98]$. In a Dutch cohort, colonization with Clostridium difficile in the first month of life was associated with AD up to age seven, and colonization with Escherichia coli was associated with a higher risk of AD at age two $[99,100]$. In addition, studies of both adult and infant populations have observed greater colonization with enterobacteriaceae in AD [101,102]. Faecalibacterium prausnitzii has also been found to be significantly elevated in the AD population [103,104]. Other bacteria are found to less frequently colonize AD populations, such as bifidobacteria [95,102]. Although there is still much work to be done in identifying and analyzing gut microbiota in AD compared to healthy populations, the science shows that there are several distinct differences between these groups that are likely contributing to disease manifestation.

Patients with $\mathrm{AD}$ are typically treated with a combination of emollients and antimicrobial, anti-inflammatory, and/or systemic immunosuppressant medications. More recently, researchers have explored how these interventions affect not only disease severity, but also the composition of the skin microbiome. Open and double-blind placebo-controlled trials have demonstrated that oral and topical antimicrobial treatments can reduce $S$. aureus skin colonization and lead to improvement in disease severity $[83,105,106]$. However, studies exploring the effects of systemic antibiotics alone have not demonstrated long-term improvement in AD skin lesions and revealed only transient decreases in the cutaneous S. aureus burden $[107,108]$. A study comparing the efficacy of a combination topical steroid/topical antibiotic versus steroid alone also failed to show superior improvement in AD severity or S. aureus colonization in the antibiotic-treated cohort [85]. More than just decreasing S. aureus colonization, studies also clearly show that treatment of AD lesions with a variety of interventions restores diversity to the cutaneous microbiota. A single-blind placebo-controlled trial demonstrated that treatment with a topical corticosteroid alone was non-inferior to steroids plus bleach baths in improving AD lesions and restoring the microbial milieu to that of non-lesional AD skin [109]. Similarly, 
a study investigating microbial populations on intermittently-treated AD skin (topical corticosteroids, calcineurin inhibitors, or antibiotics in the last seven days, and/or oral antibiotics within the last four weeks) versus untreated AD skin, found that intermittently-treated skin had less S. aureus and more microbial diversity [4]. Additionally, increases in Streptococcus, Corynebacteria, and Propionibacteria were seen following therapy. Another study found that even when only emollients are used in lesional AD skin, the diversity of cutaneous microorganisms is increased and restored to that of unaffected skin [110]. Prevention and treatment of AD through the administration of oral probiotic supplements in pregnancy and in infancy has shown modest improvement in AD in some cases, but has yet to become a mainstay of treatment therapy, and the effects of supplementation on the microbiome specifically are less explored [111]. These data emphasize the value of modulating the dysbiotic microbiome, through a variety of interventions, as an important therapeutic principle of $\mathrm{AD}$ treatment.

While it is tempting to draw conclusions from the expanding literature on the microbiome and atopic dermatitis, there are several caveats that must be kept in mind. Studies on the topic involve populations from different countries, with unique diets, hygiene, and genetic predispositions that all have the potential to alter or confound findings. Moreover, as technology has advanced, more detailed information about the microbiotic composition has become available, and we must ask whether undetected bacterial strains were present in the subjects of earlier studies. Lastly, there are sites along the aerodigestive tract outside of the intestines that may contribute to the microbiome and play an additional part in the development of AD. In order to identify how the microbiomes of each body site may work together to influence the manifestation of $\mathrm{AD}$, large studies among well-characterized birth cohorts with long-term follow-up are essential. Understanding how all of the bacterial communities interact and affect one another is needed to fully understand and effectively treat this disease.

\subsection{Rosacea}

Rosacea is a chronic inflammatory condition of facial skin that affects between $0.9 \%$ and $10 \%$ of the American and European population [112]. It is classically identified by facial flushing or persistent facial erythema, telangiectasia, and/or inflammatory papules and pustules [113]. The pathogenesis is not fully understood but the clinical manifestations of rosacea are multifactorial and are at least in part due to abnormal neurovascular activation, dysregulated production and release of inflammatory molecules, and overgrowth of organisms that naturally inhabit the skin [114].

How the cutaneous microbiome differs in rosacea has been the subject of many scientific investigations. Demodex folliculorum (a.k.a. demodex), a mite that lives in the sebaceous glands of healthy skin, is a commonly implicated pathogen in rosacea, as it has been found in numerous studies to exist in excess on the skin of afflicted patients [115-118]. Further, skin biopsies with higher counts of demodex show prominent inflammatory cell populations around hair follicles and have greater expression of genes encoding inflammatory peptides and cellular growth factors $[117,119]$. It has been postulated that the mite exoskeleton stimulates production of some of these pathogenic mediators [120]. Still, demodex is unlikely to be the only cutaneous microbiotic component contributing to the disease. One study showed that although treatment of rosacea with topical anti-demodex cream (permethrin $5 \%$ ) decreased demodex counts significantly, it was not superior to topical antibiotics (metronidazole $0.75 \%$ ) in improving rosacea, suggesting bacterial pathogens may be involved [121]. Demodex mites are suspected carriers of Bacillus oleronius, pro-inflammatory, gram-negative bacteria that are susceptible to many antibiotics commonly used to treat rosacea, including doxycycline [122-124]. Staphylococcus epidermidis, a healthy skin commensal, has also been isolated from rosacea pustules [125]. Yet, in comparison to the non-hemolytic S. epidermidis found on healthy controls, the S. epidermidis isolated from rosacea patients was a beta-hemolytic variant with possible increased virulence [126]. It was previously presumed that antibiotic therapy improved rosacea primarily through its anti-inflammatory effects, but these studies suggest that an anti-bacterial mechanism is also at play.

Alterations in the gut microbiome have also been implicated in rosacea pathogenesis. A small cross-sectional study comparing the gut microbiota of those with and without rosacea found several 
differences between groups, with certain bacteria being more abundant in rosacea patients, and other bacteria populations being less abundant. In contrast with atopic dermatitis, metagenomics showed no difference in the microbiotic diversity of subject groups [127]. The most-studied gut bacterium in its relation to rosacea is Helicobacter pylori, a gram-negative organism that resides in the stomach of approximately $50 \%$ of the population [128-131]. Although $H$. pylori colonization is usually asymptomatic, it is also a well-known cause of dyspepsia, gastric and duodenal ulcers, and various GI malignancies [132]. Assessing H. pylori's contribution to rosacea can be difficult, as standard treatment of both afflictions is with oral antibiotics. However, in studies that controlled for prior antibiotic use, H. pylori IgG seropositivity was strongly correlated with rosacea $[133,134]$. Further supporting an association, rosacea severity has been shown to decrease with eradication of H. pylori [135-137]. Again, it is unclear if treatment with antibiotics confounded these results. Though the exact pathway between $H$. pylori infection and rosacea has not been fully elucidated, studies suggest it may exert effects through its pro-inflammatory virulence peptides, particularly in those with concomitant gastrointestinal symptoms [138,139]. Nonetheless, the association with H. pylori and rosacea remains controversial, as other studies have not found a correlation between the two entities [140-142]. It is still debated whether dysbiosis occurs in response to rosacea, or is a cause [114]. Ultimately, more studies exploring the microbiome and rosacea are needed to further clarify their relationship with one another.

\subsection{Psoriasis}

Psoriasis is a chronic inflammatory skin disease that is estimated to affect $2-3 \%$ of the population, often appearing between 15-25 years of age [143]. Classically, it is characterized by raised, scaly, well-demarcated, erythematous lesions on extensor surfaces and can be intensely pruritic [143]. In some cases, extracutaneous manifestations of psoriasis, such as ocular or joint involvement can be seen [144]. Although the mechanism of disease is unclear, its pathology is believed to be multifactorial, involving strong genetic factors, disruptions to the immune system, and environmental triggers [145].

Investigation into the skin microbiome has cemented the role of skin flora dysbiosis in psoriasis. Many have attempted to characterize the bacterial composition of the skin microbiota in psoriatic lesions. Gao et al. used 16S rDNA PCR to compare affected to non-affected skin from 6 patients and found that Firmicutes was significantly overrepresented in psoriatic lesions compared to healthy skin, while Actinobacteria was significantly underrepresented [146]. However, another study found the complete opposite- there was a significant decrease in Firmicutes and Staphylococcus in affected skin compared to non-affected skin [147]. A similar study identified Corynebacterium, Propionibacterium, Staphylococcus, and Streptococcus as the major bacterial genera located on lesional and non-lesional skin from psoriasis patients, with a significant abundance in Firmicutes and Actinobacteria. There was a continual decrease in bacterial diversity observed in non-lesional and lesional skin from psoriasis patients when compared to healthy controls, suggesting that dysregulation of the skin microbiome seen in psoriasis is not limited to lesional skin, but affects the entire cutaneous microbiota as a whole [148].

Interestingly, S. aureus is known colonize the skin in psoriasis more abundantly in comparison to those without psoriasis [149], although it is rare for S. aureus to cause an overt infection. Chang et al. also found an abundance of Staphylococcus aureus in lesional and non-lesional skin from patients with psoriasis, compared to healthy controls [150]. To understand the significance, they used a mouse model to explore the effects of $S$. aureus on $T$ cell differentiation and found that mice colonized with S. aureus demonstrated a strong Th17 polarization compared to mice colonized with S. epidermis [150]. Their results suggest that $S$. aureus is capable of upregulating a Th17 response, initiating the release of pro-inflammatory cytokines, and contributing to the inflammation observed in psoriasis. These cumulative efforts have led to the conclusion that psoriasis is associated with dysregulation in composition and a decrease in diversity of the cutaneous microbiota at both affected and unaffected sites. However, characteristics of the bacterial microbiome in a disease versus healthy state remains unclear. 
Few studies have looked at the effect of treatment on the skin microbiome in psoriasis. One study analyzed the skin microbiome of patients with chronic plaque-type psoriasis before and after treatment with narrowband UVB (nbUVB). Those with at least a 75\% reduction in the Psoriasis Severity Index (PSI) score demonstrated a significant decrease in Firmicutes, Pseudomonas, Staphylococcus, Finegoldia, Anaerococcus, Peptoniphilus, Gardnerella, Prevotella and Clostridium after nbUVB treatment [147]. Another study found that 3 weeks of selenium-rich water balneotherapy treatment resulted in an increase in Xanthomonadaceae — a bacteria with known keratolytic activity—and subsequent clinical improvement in the Psoriasis Area and Severity Index (PASI) score [151]. These limited studies suggest a promising role for microbiome-targeted treatment, but a causal relationship between successful treatment and modification of the skin microbiome cannot be concluded based on these results alone.

Psoriasis, like many other systemic inflammatory diseases, likely involves inappropriate activation of various immune pathways leading to elevations in pro-inflammatory cytokines. The gut microbiome is believed to be involved in the development of pro-inflammatory Th17 cells, allowing it to modulate inflammation in diseases such as inflammatory bowel disease and obesity [152]. Like the skin microbiota, the composition of the gut microbiota and its relation to psoriatic disease is unclear. Tan et al. compared the gut microbiota in patients with psoriasis to those without and found that those with psoriasis had a significant decrease in Akkermansia muciniphila, a species believed to strengthen the integrity of the gut epithelium and protect against systemic inflammatory diseases such as inflammatory bowel disease, obesity, and atherosclerosis [152-156]. Scher et al. found a decrease in bacterial diversity in the gut of patients with psoriatic arthritis and skin-limited psoriasis [157]. Two groups described a decrease in Actinobacteria compared to healthy controls. One group found that an elevated Firmicutes to Bacteroidetes ratio in psoriatic patients, was positively correlated with PASI score $[157,158]$. Interestingly, this abnormality is also correlated with the increased inflammation observed $[159,160]$. However, contrary to these some of these findings, Codoñer et al. saw an increase in bacterial diversity, overrepresentation of Faecalibacterium, Akkermansia, and Ruminococcus, and a decrease in Bacteroides in 52 patients with psoriasis [161]. Several confounding factors could play a role in these discrepancies including differences in study population as well as changes in technology.

Although most treatment for psoriasis do not involve direct modulation of the gut microbiome, evidence suggests that there may be a potential role for it. One study explored the role of the gut microbiota in murine-models of psoriasis. They found that mice reared in germ-free conditions and mice treated with antibiotics developed less severe imiquimod-induced skin inflammation than conventional mice. Mice treated with antibiotics had a significant increase in Lactobacilalles-lactic-acid producing bacteria with anti-inflammatory effects in a healthy gut. The mice reared in germ-free conditions and mice treated with antibiotics also had a reduction in Th17 cells compared to conventional mice [162]. Together, these findings demonstrate that a lack of gut microbiota results in resistance to the development of psoriasis, possibly through preventing the development of Th17 cells and a reduction in the pro-inflammatory pathway. This study further elucidates the importance of the gut microbiome in the development of psoriasis and suggests a role for antibiotics in reducing acute exacerbations of psoriasis. Future studies are needed to see if these findings can be extrapolated to human subjects.

\subsection{Seborrheic Dermatitis}

Seborrheic dermatitis (SD) is a common inflammatory rash that most often occurs on areas of skin with a high density of sebaceous glands, such as the scalp, face, and trunk [163]. Outbreaks of SD often correlate with specific triggers, such as weather change, depression, and emotional stress [164]. The incidence of SD peaks at three ages: infancy, teenage years, and adults over 50 years old, suggesting that hormonal changes in sebum production play one role in its pathogenesis. Although SD commonly occurs in generally healthy individuals, it is especially prevalent in people with Parkinson's disease or those infected with human immunodeficiency virus (HIV) [165]. In addition to being associated with sebum-rich hair-bearing areas, seborrheic dermatitis is associated with Malassezia, ubiquitous fungi that is normally a part of the human skin microbiome. However, the role of Malassezia in the 
development of SD is still poorly understood [166]. Tanaka et al. recently used pyrosequencing and quantitative polymerase chain reaction to characterize the bacterial microbes on skin with and without SD. The investigators found that Actinetobacter, Staphylococcus, and Streptococcus dominated the skin microbiome of lesional skin affected with SD compared to nonlesional skin [167]. In a cohort study of patients with SD, An et al. found that patients with SD had a significantly higher colonization with Staphylococcus epidermidis than those without SD [163]. To better understand this association, more clinical studies are needed investigating how the skin microbiome compares between affected and unaffected individuals, and how the microbial composition is changed after treatment. As researchers learn more about the role of the skin microbiome in the etiology of SD, more targeted treatment approaches can be developed towards implicated microbial organisms.

\section{Role of Probiotics and Prebiotics}

Probiotics are defined as "live microorganisms which when administered in adequate amounts confer a health benefit to the host" [168]. Probiotics have become more popular over the last twenty years, as research has suggested that they may be beneficial to many aspects of human health such as in the prevention of antibiotic-associated diarrhea and in the treatment and prevention of infectious diarrhea [169]. The most commonly used bacteria are lactobacilli and bifidobacteria [170]. Prebiotics are non-digestible food ingredients, which are able to benefit the host by selectively stimulating the growth and or activity of bacterial species present in the colon. The most common prebiotics are non-digestible oligosaccharides. Synbiotics are a combination of prebiotics and probiotics [171].

There have been numerous studies investigating the use of prebiotics and probiotics in both the treatment and prevention of atopic dermatitis $(\mathrm{AD})$ in children. A recent meta-analysis by Huang et al. identified thirteen studies in children with AD. They found increased efficacy of probiotics in treating AD in children in the 1-18 year subgroup [172]. Regarding disease prevention, a meta-analysis by Lee et al. found a significant risk reduction in pediatric atopic dermatitis with the administration of prenatal or postnatal probiotic supplementation. However, they did not find evidence to support the use of probiotics in the treatment of established $\mathrm{AD}$ [173]. A reduction in pediatric atopic dermatitis following maternal supplementation has also been supported by other meta-analyses [174]. In contrast, meta-analyses have generally failed to demonstrate much benefit of probiotics in the treatment of established AD. However, it should be noted that individual trials assessing treatment outcomes were smaller and exhibited more heterogeneity in comparison to the prevention studies [173]. Far fewer studies have been conducted addressing the use of probiotics in the treatment adults with AD. A meta-analyses of four studies in adults with $\mathrm{AD}$ found a mean weighted difference of $-8.26,95 \% \mathrm{CI}-13.28$ to -3.25 [173].

There is one reported case of probiotics being used to successfully treat pustular psoriasis in India [175]. However, a randomized control trial examined the use of probiotics in the treatment of spondyloarthritis patients, including psoriasis and psoriatic arthritis, and found no significant change in disease severity compared to placebo [176]. Further research needs to be conducted regarding the use of probiotics in other dermatological disease such as acne, rosacea, wound healing, and psoriasis [177]. Probiotics should not all be classified as one intervention as there are differences among probiotics depending on the species, genus, or where they are a spore-former or not.

\section{On the Horizon: Gut-Skin Communication}

If it is hypothesized that changes to the gut microbiome can lead to cutaneous manifestations, the question becomes, 'how?'. The "brain-gut-skin axis", was initially proposed by John H. Stokes and Donald M. Pillsbury in 1930 [178]. They hypothesized that negative emotional states such as depression and anxiety alter the gastrointestinal function and lead to changes in normal gut flora, increased intestinal permeability, and systemic inflammation [178]. A study demonstrating that mice fed probiotics demonstrated reduced stress-induced neurogenic skin inflammation when compared to control mice. Although the mechanism was not elucidated, the authors suggested that increased epithelial permeability in the gut triggers T-cell activation and disrupts immunosuppressive cytokines 
and $\mathrm{T}$ regulatory cells responsible for establishing tolerance, leading to systemic inflammation that can disrupt cutaneous homeostasis [179]. Additionally, it has been suggested that altered levels of neurotransmitters, such as acetylcholine, norepinephrine, and dopamine produced by gut organisms can communicate with peripheral organs through neuronal pathways not yet identified [180].

Another theory is that increased intestinal permeability associated with altered gut flora allows for direct migration of inflammatory products into the systemic circulation. In a study involving obese mice, Cani et al. demonstrated that modifications in diet, namely excess dietary fat, facilitates increased absorption of highly proinflammatory lipopolysaccharide (LPS, a membrane component of Gram-negative bacteria) from the gut, and contributed to chronic low-grade systemic inflammation and the development of metabolic disease [181]. Research in psoriasis patients found that they actually had increased levels of bacterial DNA in the bloodstream compared to healthy controls. In a study involving 54 patients with psoriasis and 27 controls, bacterial DNA was detected in the bloodstream of 16 patients with plaque psoriasis and in none of the control patients [182]. These patients with serum bacterial DNA also exhibited significantly higher levels of systemic inflammatory response markers, including IL-1 $\beta$, IL-6, IL-12, tumor necrosis factor, and interferon $\gamma$. It is presumed that the bacterial DNA would have originated from the intestinal lumen and suggests that decreased integrity of the gut epithelium is involved in the pathogenesis of psoriasis. A 2018 study did not identify a specific bacterium responsible for bacterial DNA translocation (BT), arguing that there is not a specific gut microbial composition that allows for increased likelihood of bacterial DNA translocation, but rather, inflammation from an overall microbial imbalance [161].

Although it is apparent that there is a link between the gut microbiota and dermatological disease, the exact mechanism is poorly understood. Current evidence suggests that it is likely due to a combination of both neurologic and immunologic responses to environmental shifts, resulting in chronic systemic inflammation that can ultimately affect the skin. Further studies need to go beyond descriptive microbiome studies, to include functional characteristics such as transcriptomics, lipidomics, and secondary metabolite measures, as this will allow us to better understand the method of communication between the gut and the skin in order to design therapies that effectively target multiple aspects of disease pathogenesis.

Author Contributions: Conceptualization, S.R.E. and R.K.S.; Writing-initial draft preparation, S.R.E., M.N. (Mimi Nguyen), A.R.V., M.N. (Manisha Notay), W.A.B., Writing—review and editing, S.R.E., M.N. (Mimi Nguyen), S.S., R.K.S.; Supervision, R.K.S.

Funding: This research received no external funding.

Conflicts of Interest: RKS serves as scientific advisor and editor to LearnHealth and as a consultant to Burt's Bees and Dermala. MN, AV, MN, WB, and SS have no conflicts of interest to disclose.

\section{References}

1. Marples, R.R. The microflora of the face and acne lesions. J. Investig. Dermatol. 1974, 62, 326-331. [CrossRef] [PubMed]

2. Grice, E.A.; Kong, H.H.; Renaud, G.; Young, A.C.; Program, N.C.S.; Bouffard, G.G.; Blakesley, R.W.; Wolfsberg, T.G.; Turner, M.L.; Segre, J.A. A diversity profile of the human skin microbiota. Genome Res. 2008, 18, 1043-1050. [CrossRef] [PubMed]

3. Grice, E.A.; Segre, J.A. The skin microbiome. Nat. Rev. Microbiol. 2011, 9, 244-253. [CrossRef] [PubMed]

4. Kong, H.H.; Oh, J.; Deming, C.; Conlan, S.; Grice, E.A.; Beatson, M.A.; Nomicos, E.; Polley, E.C.; Komarow, H.D.; Program, N.C.S.; et al. Temporal shifts in the skin microbiome associated with disease flares and treatment in children with atopic dermatitis. Genome Res. 2012, 22, 850-859. [CrossRef] [PubMed]

5. Oh, J.; Byrd, A.L.; Deming, C.; Conlan, S.; Program, N.C.S.; Kong, H.H.; Segre, J.A. Biogeography and individuality shape function in the human skin metagenome. Nature 2014, 514, 59-64. [CrossRef] [PubMed]

6. Christensen, G.J.; Scholz, C.F.; Enghild, J.; Rohde, H.; Kilian, M.; Thurmer, A.; Brzuszkiewicz, E.; Lomholt, H.B.; Bruggemann, H. Antagonism between Staphylococcus epidermidis and Propionibacterium acnes and its genomic basis. BMC Genom. 2016, 17, 152. [CrossRef] [PubMed] 
7. Haque, N.; Hossain, M.A.; Bilkis, L.; Musa, A.K.; Mahamud, C.; Bari, M.S.; Haque, N.; Muhammad, N.; Parvin, U.S.; Islam, M.T.; et al. Antibiotic susceptibility pattern of Staphylococcus epidermidis. Mymensingh Med. J. 2009, 18, 142-147. [PubMed]

8. Hellmark, B.; Unemo, M.; Nilsdotter-Augustinsson, A.; Soderquist, B. Antibiotic susceptibility among Staphylococcus epidermidis isolated from prosthetic joint infections with special focus on rifampicin and variability of the rpoB gene. Clin. Microbiol. Infect. 2009, 15, 238-244. [CrossRef] [PubMed]

9. Holland, K.T.; Cunliffe, W.J.; Eady, E.A. Intergeneric and intrageneric inhibition between strains of Propionibacterium acnes and micrococcaceae, particularly Staphylococcus epidermidis, isolated from normal skin and acne lesions. J. Med. Microbiol. 1979, 12, 71-82. [CrossRef] [PubMed]

10. Nakatsuji, T.; Chen, T.H.; Narala, S.; Chun, K.A.; Two, A.M.; Yun, T.; Shafiq, F.; Kotol, P.F.; Bouslimani, A.; Melnik, A.V.; et al. Antimicrobials from human skin commensal bacteria protect against Staphylococcus aureus and are deficient in atopic dermatitis. Sci. Transl. Med. 2017, 9, eaah4680. [CrossRef] [PubMed]

11. Wu, X.; Santos, R.R.; Fink-Gremmels, J. Staphylococcus epidermidis biofilm quantification: Effect of different solvents and dyes. J. Microbiol. Methods 2014, 101, 63-66. [CrossRef] [PubMed]

12. Naik, S.; Bouladoux, N.; Linehan, J.L.; Han, S.J.; Harrison, O.J.; Wilhelm, C.; Conlan, S.; Himmelfarb, S.; Byrd, A.L.; Deming, C.; et al. Commensal-dendritic-cell interaction specifies a unique protective skin immune signature. Nature 2015, 520, 104-108. [CrossRef] [PubMed]

13. Naik, S.; Bouladoux, N.; Wilhelm, C.; Molloy, M.J.; Salcedo, R.; Kastenmuller, W.; Deming, C.; Quinones, M.; Koo, L.; Conlan, S.; et al. Compartmentalized control of skin immunity by resident commensals. Science 2012, 337, 1115-1119. [CrossRef] [PubMed]

14. Linehan, J.L.; Harrison, O.J.; Han, S.J.; Byrd, A.L.; Vujkovic-Cvijin, I.; Villarino, A.V.; Sen, S.K.; Shaik, J.; Smelkinson, M.; Tamoutounour, S.; et al. Non-classical Immunity Controls Microbiota Impact on Skin Immunity and Tissue Repair. Cell 2018, 172, 784-796.e718. [CrossRef] [PubMed]

15. Eckburg, P.B.; Bik, E.M.; Bernstein, C.N.; Purdom, E.; Dethlefsen, L.; Sargent, M.; Gill, S.R.; Nelson, K.E.; Relman, D.A. Diversity of the human intestinal microbial flora. Science 2005, 308, 1635-1638. [CrossRef] [PubMed]

16. Costello, E.K.; Lauber, C.L.; Hamady, M.; Fierer, N.; Gordon, J.I.; Knight, R. Bacterial community variation in human body habitats across space and time. Science 2009, 326, 1694-1697. [CrossRef] [PubMed]

17. Sommer, F.; Backhed, F. The gut microbiota-masters of host development and physiology. Nat. Rev. Microbiol. 2013, 11, 227-238. [CrossRef] [PubMed]

18. Livingstone, K.M.; Givens, D.I.; Jackson, K.G.; Lovegrove, J.A. Comparative effect of dairy fatty acids on cell adhesion molecules, nitric oxide and relative gene expression in healthy and diabetic human aortic endothelial cells. Atherosclerosis 2014, 234, 65-72. [CrossRef] [PubMed]

19. Brestoff, J.R.; Artis, D. Commensal bacteria at the interface of host metabolism and the immune system. Nat. Immunol. 2013, 14, 676-684. [CrossRef] [PubMed]

20. Clarke, T.B.; Davis, K.M.; Lysenko, E.S.; Zhou, A.Y.; Yu, Y.; Weiser, J.N. Recognition of peptidoglycan from the microbiota by Nod1 enhances systemic innate immunity. Nat. Med. 2010, 16, 228-231. [CrossRef] [PubMed]

21. Delzenne, N.M.; Williams, C.M. Prebiotics and lipid metabolism. Curr. Opin. Lipidol. 2002, 13, 61-67. [CrossRef] [PubMed]

22. Backhed, F.; Ley, R.E.; Sonnenburg, J.L.; Peterson, D.A.; Gordon, J.I. Host-bacterial mutualism in the human intestine. Science 2005, 307, 1915-1920. [CrossRef] [PubMed]

23. Sharon, G.; Garg, N.; Debelius, J.; Knight, R.; Dorrestein, P.C.; Mazmanian, S.K. Specialized metabolites from the microbiome in health and disease. Cell Metab. 2014, 20, 719-730. [CrossRef] [PubMed]

24. Rodriguez-Carrio, J.; Salazar, N.; Margolles, A.; Gonzalez, S.; Gueimonde, M.; de Los Reyes-Gavilan, C.G.; Suarez, A. Free Fatty Acids Profiles Are Related to Gut Microbiota Signatures and Short-Chain Fatty Acids. Front. Immunol. 2017, 8, 823. [CrossRef] [PubMed]

25. Esgalhado, M.; Kemp, J.A.; Damasceno, N.R.; Fouque, D.; Mafra, D. Short-chain fatty acids: A link between prebiotics and microbiota in chronic kidney disease. Future Microbiol. 2017, 12, 1413-1425. [CrossRef] [PubMed]

26. Hague, A.; Elder, D.J.; Hicks, D.J.; Paraskeva, C. Apoptosis in colorectal tumour cells: Induction by the short chain fatty acids butyrate, propionate and acetate and by the bile salt deoxycholate. Int. J. Cancer 1995, 60, 400-406. [CrossRef] [PubMed]

27. Schaeffler, A.; Gross, P.; Buettner, R.; Bollheimer, C.; Buechler, C.; Neumeier, M.; Kopp, A.; Schoelmerich, J.; Falk, W. Fatty acid-induced induction of Toll-like receptor-4/nuclear factor-kappaB pathway in adipocytes links nutritional signalling with innate immunity. Immunology 2009, 126, 233-245. [CrossRef] [PubMed] 
28. Honda, K.L.; Lamon-Fava, S.; Matthan, N.R.; Wu, D.; Lichtenstein, A.H. EPA and DHA exposure alters the inflammatory response but not the surface expression of Toll-like receptor 4 in macrophages. Lipids 2015, 50, 121-129. [CrossRef] [PubMed]

29. Frommer, K.W.; Schaffler, A.; Rehart, S.; Lehr, A.; Muller-Ladner, U.; Neumann, E. Free fatty acids: Potential proinflammatory mediators in rheumatic diseases. Ann. Rheum. Dis. 2015, 74, 303-310. [CrossRef] [PubMed]

30. Haversen, L.; Danielsson, K.N.; Fogelstrand, L.; Wiklund, O. Induction of proinflammatory cytokines by long-chain saturated fatty acids in human macrophages. Atherosclerosis 2009, 202, 382-393. [CrossRef] [PubMed]

31. Serhan, C.N.; Chiang, N.; Van Dyke, T.E. Resolving inflammation: Dual anti-inflammatory and pro-resolution lipid mediators. Nat. Rev. Immunol. 2008, 8, 349-361. [CrossRef] [PubMed]

32. Hung, A.M.; Booker, C.; Ellis, C.D.; Siew, E.D.; Graves, A.J.; Shintani, A.; Abumrad, N.N.; Himmelfarb, J.; Ikizler, T.A. Omega-3 fatty acids inhibit the up-regulation of endothelial chemokines in maintenance hemodialysis patients. Nephrol. Dial. Transplant. 2015, 30, 266-274. [CrossRef] [PubMed]

33. Miles, E.A.; Thies, F.; Wallace, F.A.; Powell, J.R.; Hurst, T.L.; Newsholme, E.A.; Calder, P.C. Influence of age and dietary fish oil on plasma soluble adhesion molecule concentrations. Clin. Sci. 2001, 100, 91-100. [CrossRef] [PubMed]

34. Moraes, C.; Fouque, D.; Amaral, A.C.; Mafra, D. Trimethylamine N-Oxide From Gut Microbiota in Chronic Kidney Disease Patients: Focus on Diet. J. Ren. Nutr. 2015, 25, 459-465. [CrossRef] [PubMed]

35. De Angelis, M.; Garruti, G.; Minervini, F.; Bonfrate, L.; Portincasa, P.; Gobbetti, M. The food-gut human axis: The effects of diet on gut microbiota and metabolome. Curr. Med. Chem. 2017, 26, 3567-3583. [CrossRef] [PubMed]

36. Watson, H.; Mitra, S.; Croden, F.C.; Taylor, M.; Wood, H.M.; Perry, S.L.; Spencer, J.A.; Quirke, P.; Toogood, G.J.; Lawton, C.L.; et al. A randomised trial of the effect of omega-3 polyunsaturated fatty acid supplements on the human intestinal microbiota. Gut 2017, 67, 1974-1983. [CrossRef] [PubMed]

37. Ahmad, O.F.; Akbar, A. Microbiome, antibiotics and irritable bowel syndrome. Br. Med. Bull. 2016, 120, 91-99. [CrossRef] [PubMed]

38. Dicksved, J.; Halfvarson, J.; Rosenquist, M.; Jarnerot, G.; Tysk, C.; Apajalahti, J.; Engstrand, L.; Jansson, J.K. Molecular analysis of the gut microbiota of identical twins with Crohn's disease. ISME J. 2008, 2, 716-727. [CrossRef] [PubMed]

39. Ley, R.E.; Turnbaugh, P.J.; Klein, S.; Gordon, J.I. Microbial ecology: Human gut microbes associated with obesity. Nature 2006, 444, 1022-1023. [CrossRef] [PubMed]

40. Turnbaugh, P.J.; Backhed, F.; Fulton, L.; Gordon, J.I. Diet-induced obesity is linked to marked but reversible alterations in the mouse distal gut microbiome. Cell Host Microbe 2008, 3, 213-223. [CrossRef] [PubMed]

41. Claesson, M.J.; O'Sullivan, O.; Wang, Q.; Nikkila, J.; Marchesi, J.R.; Smidt, H.; de Vos, W.M.; Ross, R.P.; O'Toole, P.W. Comparative analysis of pyrosequencing and a phylogenetic microarray for exploring microbial community structures in the human distal intestine. PLoS ONE 2009, 4, e6669. [CrossRef] [PubMed]

42. Palmer, C.; Bik, E.M.; DiGiulio, D.B.; Relman, D.A.; Brown, P.O. Development of the human infant intestinal microbiota. PLOS Biol. 2007, 5, e177. [CrossRef] [PubMed]

43. Turnbaugh, P.J.; Hamady, M.; Yatsunenko, T.; Cantarel, B.L.; Duncan, A.; Ley, R.E.; Sogin, M.L.; Jones, W.J.; Roe, B.A.; Affourtit, J.P.; et al. A core gut microbiome in obese and lean twins. Nature 2009, 457, 480-484. [CrossRef] [PubMed]

44. Lozupone, C.A.; Stombaugh, J.I.; Gordon, J.I.; Jansson, J.K.; Knight, R. Diversity, stability and resilience of the human gut microbiota. Nature 2012, 489, 220-230. [CrossRef] [PubMed]

45. Kishishita, M.; Ushijima, T.; Ozaki, Y.; Ito, Y. Biotyping of Propionibacterium acnes isolated from normal human facial skin. Appl. Env. Microbiol. 1979, 38, 585-589.

46. Puhvel, S.M. Characterization of Corynebacterium acnes. J. Gen. Microbiol. 1968, 50, 313-320. [CrossRef] [PubMed]

47. Takizawa, K. A study on the characterization of Corynebacterium acnes. J. Dermatol. 1977, 4, 193-202. [CrossRef] [PubMed]

48. Whiteside, J.A.; Voss, J.G. Incidence and lipolytic activity of Propionibacterium acnes (Corynebacterium acnes group I) and P. granulosum (C. acnes group II) in acne and in normal skin. J. Investig. Dermatol. 1973, 60, 94-97. [CrossRef] [PubMed]

49. Dagnelie, M.A.; Khammari, A.; Dreno, B.; Corvec, S. Cutibacterium acnes molecular typing: Time to standardize the method. Clin. Microbiol. Infect. 2018, 24, 1149-1155. [CrossRef] [PubMed] 
50. Fitz-Gibbon, S.; Tomida, S.; Chiu, B.H.; Nguyen, L.; Du, C.; Liu, M.; Elashoff, D.; Erfe, M.C.; Loncaric, A.; Kim, J.; et al. Propionibacterium acnes strain populations in the human skin microbiome associated with acne. J. Investig. Dermatol. 2013, 133, 2152-2160. [CrossRef] [PubMed]

51. Higaki, S.; Kitagawa, T.; Kagoura, M.; Morohashi, M.; Yamagishi, T. Correlation between Propionibacterium acnes Biotypes, Lipase Activity and Rash Degree in Acne Patients. J. Dermatol. 2000, 27, 519-522. [CrossRef] [PubMed]

52. Lomholt, H.B.; Kilian, M. Population genetic analysis of Propionibacterium acnes identifies a subpopulation and epidemic clones associated with acne. PLoS ONE 2010, 5, e12277. [CrossRef] [PubMed]

53. McDowell, A.; Valanne, S.; Ramage, G.; Tunney, M.M.; Glenn, J.V.; McLorinan, G.C.; Bhatia, A.; Maisonneuve, J.F.; Lodes, M.; Persing, D.H.; et al. Propionibacterium acnes types I and II represent phylogenetically distinct groups. J. Clin. Microbiol. 2005, 43, 326-334. [CrossRef] [PubMed]

54. Kasimatis, G.; Fitz-Gibbon, S.; Tomida, S.; Wong, M.; Li, H. Analysis of complete genomes of Propionibacterium acnes reveals a novel plasmid and increased pseudogenes in an acne associated strain. Biomed. Res. Int. 2013, 2013, 918320. [CrossRef] [PubMed]

55. Tomida, S.; Nguyen, L.; Chiu, B.H.; Liu, J.; Sodergren, E.; Weinstock, G.M.; Li, H. Pan-genome and comparative genome analyses of propionibacterium acnes reveal its genomic diversity in the healthy and diseased human skin microbiome. mBio 2013, 4, e0003-e00013. [CrossRef] [PubMed]

56. Barnard, E.; Shi, B.; Kang, D.; Craft, N.; Li, H. The balance of metagenomic elements shapes the skin microbiome in acne and health. Sci. Rep. 2016, 6, 39491. [CrossRef] [PubMed]

57. Marinelli, L.J.; Fitz-Gibbon, S.; Hayes, C.; Bowman, C.; Inkeles, M.; Loncaric, A.; Russell, D.A.; Jacobs-Sera, D.; Cokus, S.; Pellegrini, M.; et al. Propionibacterium acnes bacteriophages display limited genetic diversity and broad killing activity against bacterial skin isolates. mBio 2012, 3. [CrossRef] [PubMed]

58. Namvar, A.E.; Bastarahang, S.; Abbasi, N.; Ghehi, G.S.; Farhadbakhtiarian, S.; Arezi, P.; Hosseini, M.; Baravati, S.Z.; Jokar, Z.; Chermahin, S.G. Clinical characteristics of Staphylococcus epidermidis: A systematic review. GMS Hyg. Infect. Ctrl. 2014, 9, Doc23. [CrossRef]

59. Bek-Thomsen, M.; Lomholt, H.B.; Kilian, M. Acne is not associated with yet-uncultured bacteria. J. Clin. Microbiol. 2008, 46, 3355-3360. [CrossRef] [PubMed]

60. Dreno, B.; Martin, R.; Moyal, D.; Henley, J.B.; Khammari, A.; Seite, S. Skin microbiome and acne vulgaris: Staphylococcus, a new actor in acne. Exp. Derm. 2017, 26, 798-803. [CrossRef] [PubMed]

61. Nishijima, S.; Kurokawa, I.; Katoh, N.; Watanabe, K. The bacteriology of acne vulgaris and antimicrobial susceptibility of Propionibacterium acnes and Staphylococcus epidermidis isolated from acne lesions. J. Dermatol. 2000, 27, 318-323. [CrossRef] [PubMed]

62. Pathak, R.; Kasama, N.; Kumar, R.; Gautam, H. Staphylococcus epidermidis in Human Skin Microbiome associated with Acne: A Cause of Disease or Defence? Res. J. Biotechnol. 2013, 8, 78-82.

63. Akaza, N.; Akamatsu, H.; Numata, S.; Yamada, S.; Yagami, A.; Nakata, S.; Matsunaga, K. Microorganisms inhabiting follicular contents of facial acne are not only Propionibacterium but also Malassezia spp. J. Dermatol. 2016, 43, 906-911. [CrossRef] [PubMed]

64. Cheikhrouhou, F.; Guidara, R.; Masmoudi, A.; Trabelsi, H.; Neji, S.; Sellami, H.; Makni, F.; Ayadi, A. Molecular Identification of Malassezia Species in Patients with Malassezia folliculitis in Sfax, Tunisia. Mycopathologia 2017, 182, 583-589. [CrossRef] [PubMed]

65. Levy, A.; Feuilhade de Chauvin, M.; Dubertret, L.; Morel, P.; Flageul, B. [Malassezia folliculitis: Characteristics and therapeutic response in 26 patients]. Ann. Dermatol. Venereol. 2007, 134, 823-828. [PubMed]

66. Omran, A.N.; Mansori, A.G. Pathogenic Yeasts Recovered From Acne Vulgaris: Molecular Characterization and Antifungal Susceptibility Pattern. Indian J. Dermatol. 2018, 63, 386-390. [CrossRef] [PubMed]

67. Prohic, A.; Jovovic Sadikovic, T.; Krupalija-Fazlic, M.; Kuskunovic-Vlahovljak, S. Malassezia species in healthy skin and in dermatological conditions. Int. J. Dermatol. 2016, 55, 494-504. [CrossRef] [PubMed]

68. Song, H.S.; Kim, S.K.; Kim, Y.C. Comparison between Malassezia Folliculitis and Non-Malassezia Folliculitis. Ann. Dermatol. 2014, 26, 598-602. [CrossRef] [PubMed]

69. Wang, Y.; Kao, M.S.; Yu, J.; Huang, S.; Marito, S.; Gallo, R.L.; Huang, C.M. A Precision Microbiome Approach Using Sucrose for Selective Augmentation of Staphylococcus epidermidis Fermentation against Propionibacterium acnes. Int. J. Mol. Sci. 2016, 17, 1870. [CrossRef] [PubMed] 
70. Wang, Y.; Kuo, S.; Shu, M.; Yu, J.; Huang, S.; Dai, A.; Two, A.; Gallo, R.L.; Huang, C.M. Staphylococcus epidermidis in the human skin microbiome mediates fermentation to inhibit the growth of Propionibacterium acnes: Implications of probiotics in acne vulgaris. Appl. Microbiol. Biotechnol. 2014, 98, 411-424. [CrossRef] [PubMed]

71. Bieber, T. Atopic Dermatitis. N Engl. J. Med. 2008, 358, 1483-1494. [CrossRef] [PubMed]

72. Nutten, S. Atopic Dermatitis: Global Epidemiology and Risk Factors. Ann. Nutr. Metab. 2015, 66, 8-16. [CrossRef] [PubMed]

73. Kapoor, R.; Menon, C.; Hoffstad, O.; Bilker, W.; Leclerc, P.; Margolis, D.J. The prevalence of atopic triad in children with physician-confirmed atopic dermatitis. J. Am. Acad. Dermatol. 2008, 58, 68-73. [CrossRef] [PubMed]

74. Braback, L.; Hjern, A.; Rasmussen, F. Trends in asthma, allergic rhinitis and eczema among Swedish conscripts from farming and non-farming environments. A nationwide study over three decades. Clin. Exp. Allergy J. Br. Soc. Allergy Clin. Immunol. 2004, 34, 38-43. [CrossRef] [PubMed]

75. Heinrich, J.; Hoelscher, B.; Frye, C.; Meyer, I.; Wjst, M.; Wichmann, H.E. Trends in prevalence of atopic diseases and allergic sensitization in children in Eastern Germany. Eur. Respir. J. 2002, 19, 1040-1046. [CrossRef] [PubMed]

76. Ring, J.; Kramer, U.; Schafer, T.; Behrendt, H. Why are allergies increasing? Curr. Opin. Immunol. 2001, 13, 701-708. [CrossRef]

77. Schultz Larsen, F. Atopic dermatitis: A genetic-epidemiologic study in a population-based twin sample. J. Am. Acad. Dermatol. 1993, 28, 719-723. [CrossRef]

78. Ong, P.Y.; Ohtake, T.; Brandt, C.; Strickland, I.; Boguniewicz, M.; Ganz, T.; Gallo, R.L.; Leung, D.Y. Endogenous antimicrobial peptides and skin infections in atopic dermatitis. N. Engl. J. Med. 2002, 347, 1151-1160. [CrossRef] [PubMed]

79. Williams, M.R.; Gallo, R.L. The Role of the Skin Microbiome in Atopic Dermatitis. Curr. Allergy Asthma Rep. 2015, 15, 65. [CrossRef] [PubMed]

80. Harder, J.; Bartels, J.; Christophers, E.; Schroder, J.M. Isolation and characterization of human beta -defensin-3, a novel human inducible peptide antibiotic. J. Biol. Chem. 2001, 276, 5707-5713. [CrossRef] [PubMed]

81. Howell, M.D. The role of human beta defensins and cathelicidins in atopic dermatitis. Curr. Opin. Allergy Clin. Immunol. 2007, 7, 413-417. [CrossRef] [PubMed]

82. Grice, E.A.; Kong, H.H.; Conlan, S.; Deming, C.B.; Davis, J.; Young, A.C.; Bouffard, G.G.; Blakesley, R.W.; Murray, P.R.; Green, E.D.; et al. Topographical and Temporal Diversity of the Human Skin Microbiome. Science 2009, 324, 1190-1192. [CrossRef] [PubMed]

83. Breuer, K.; Häussler, S.; Kapp, A.; Werfel, T. Staphylococcus aureus: Colonizing features and influence of an antibacterial treatment in adults with atopic dermatitis. Br. J. Dermatol. 2002, 147, 55-61. [CrossRef] [PubMed]

84. Goh, C.L.; Wong, J.S.; Giam, Y.C. Skin colonization of Staphylococcus aureus in atopic dermatitis patients seen at the National Skin Centre, Singapore. Int. J. Dermatol. 1997, 36, 653-657. [CrossRef] [PubMed]

85. Gong, J.Q.; Lin, L.; Lin, T.; Hao, F.; Zeng, F.Q.; Bi, Z.G.; Yi, D.; Zhao, B. Skin colonization by Staphylococcus aureus in patients with eczema and atopic dermatitis and relevant combined topical therapy: A double-blind multicentre randomized controlled trial. Br. J. Dermatol. 2006, 155, 680-687. [CrossRef] [PubMed]

86. Masenga, J.; Garbe, C.; Wagner, J.; Orfanos, C.E. Staphylococcus aureus in atopic dermatitis and in nonatopic dermatitis. Int. J. Dermatol. 1990, 29, 579-582. [CrossRef] [PubMed]

87. Ogawa, T.; Katsuoka, K.; Kawano, K.; Nishiyama, S. Comparative study of staphylococcal flora on the skin surface of atopic dermatitis patients and healthy subjects. J. Dermatol. 1994, 21, 453-460. [CrossRef] [PubMed]

88. Tauber, M.; Balica, S.; Hsu, C.Y.; Jean-Decoster, C.; Lauze, C.; Redoules, D.; Viode, C.; Schmitt, A.M.; Serre, G.; Simon, M.; et al. Staphylococcus aureus density on lesional and nonlesional skin is strongly associated with disease severity in atopic dermatitis. J. Allergy Clin. Immunol. 2016, 137, 1272-1274. [CrossRef] [PubMed]

89. Kennedy, E.A.; Connolly, J.; Hourihane, J.O.B.; Fallon, P.G.; McLean, W.H.I.; Murray, D.; Jo, J.-H.; Segre, J.A.; Kong, H.H.; Irvine, A.D. Skin microbiome before development of atopic dermatitis: Early colonization with commensal staphylococci at 2 months is associated with a lower risk of atopic dermatitis at 1 year. J. Allergy Clin. Immunol. 2017, 139, 166-172. [CrossRef] [PubMed]

90. Byrd, A.L.; Deming, C.; Cassidy, S.K.B.; Harrison, O.J.; Ng, W.-I.; Conlan, S.; Belkaid, Y.; Segre, J.A.; Kong, H.H. Staphylococcus aureus and Staphylococcus epidermidis strain diversity underlying pediatric atopic dermatitis. Sci. Transl. Med. 2017, 9. [CrossRef]

91. Forno, E.; Onderdonk, A.B.; McCracken, J.; Litonjua, A.A.; Laskey, D.; Delaney, M.L.; Dubois, A.M.; Gold, D.R.; Ryan, L.M.; Weiss, S.T.; et al. Diversity of the gut microbiota and eczema in early life. Clin. Mol. Allergy 2008, 6, 11. [CrossRef] [PubMed] 
92. Abrahamsson, T.R.; Jakobsson, H.E.; Andersson, A.F.; Bjorksten, B.; Engstrand, L.; Jenmalm, M.C. Low diversity of the gut microbiota in infants with atopic eczema. J. Allergy Clin. Immunol. 2012, 129, 434-440. [CrossRef] [PubMed]

93. Ismail, I.H.; Oppedisano, F.; Joseph, S.J.; Boyle, R.J.; Licciardi, P.V.; Robins-Browne, R.M.; Tang, M.L. Reduced gut microbial diversity in early life is associated with later development of eczema but not atopy in high-risk infants. Pediatr. Allergy Immunol. 2012, 23, 674-681. [CrossRef] [PubMed]

94. Wang, M.; Karlsson, C.; Olsson, C.; Adlerberth, I.; Wold, A.E.; Strachan, D.P.; Martricardi, P.M.; Aberg, N.; Perkin, M.R.; Tripodi, S.; et al. Reduced diversity in the early fecal microbiota of infants with atopic eczema. J. Allergy Clin. Immunol. 2008, 121, 129-134. [CrossRef] [PubMed]

95. Bjorksten, B.; Naaber, P.; Sepp, E.; Mikelsaar, M. The intestinal microflora in allergic Estonian and Swedish 2-year-old children. Clin. Exp. Allergy J. Br. Soc. Allergy Clin. Immunol. 1999, 29, 342-346. [CrossRef] [PubMed]

96. Watanabe, S.; Narisawa, Y.; Arase, S.; Okamatsu, H.; Ikenaga, T.; Tajiri, Y.; Kumemura, M. Differences in fecal microflora between patients with atopic dermatitis and healthy control subjects. J. Allergy Clin. Immunol. 2003, 111, 587-591. [CrossRef] [PubMed]

97. Nowrouzian, F.L.; Lina, G.; Hodille, E.; Lindberg, E.; Hesselmar, B.; Saalman, R.; Adlerberth, I.; Wold, A.E. Superantigens and adhesins of infant gut commensal Staphylococcus aureus strains and association with subsequent development of atopic eczema. Br. J. Dermatol. 2017, 176, 439-445. [CrossRef] [PubMed]

98. Mah, K.W.; Björkstén, B.; Lee, B.W.; van Bever, H.P.; Shek, L.P.; Tan, T.N.; Lee, Y.K.; Chua, K.Y. Distinct Pattern of Commensal Gut Microbiota in Toddlers with Eczema. Int. Arch. Allergy Immunol. 2006, 140, 157-163. [CrossRef] [PubMed]

99. Penders, J.; Thijs, C.; van den Brandt, P.A.; Kummeling, I.; Snijders, B.; Stelma, F.; Adams, H.; van Ree, R.; Stobberingh, E.E. Gut microbiota composition and development of atopic manifestations in infancy: The KOALA Birth Cohort Study. Gut 2007, 56, 661. [CrossRef] [PubMed]

100. van Nimwegen, F.A.; Penders, J.; Stobberingh, E.E.; Postma, D.S.; Koppelman, G.H.; Kerkhof, M.; Reijmerink, N.E.; Dompeling, E.; van den Brandt, P.A.; Ferreira, I.; et al. Mode and place of delivery, gastrointestinal microbiota, and their influence on asthma and atopy. J. Allergy Clin. Immunol. 2011, 128, 948-955. [CrossRef] [PubMed]

101. Matsumoto, M.; Ohishi, H.; Kakizoe, K.; Benno, Y. Faecal microbiota and secretory immunogloblin a levels in adult patients with atopic dermatitis. Microb. Ecol. Health Dis. 2004, 16, 13-17. [CrossRef]

102. Yap, G.C.; Loo, E.X.; Aw, M.; Lu, Q.; Shek, L.P.; Lee, B.W. Molecular analysis of infant fecal microbiota in an Asian at-risk cohort-correlates with infant and childhood eczema. BMC Res. Notes 2014, 7, 166. [CrossRef] [PubMed]

103. Song, H.; Yoo, Y.; Hwang, J.; Na, Y.C.; Kim, H.S. Faecalibacterium prausnitzii subspecies-level dysbiosis in the human gut microbiome underlying atopic dermatitis. J. Allergy Clin. Immunol. 2016, 137, 852-860. [CrossRef] [PubMed]

104. Zheng, H.; Liang, H.; Wang, Y.; Miao, M.; Shi, T.; Yang, F.; Liu, E.; Yuan, W.; Ji, Z.-S.; Li, D.-K. Altered Gut Microbiota Composition Associated with Eczema in Infants. PLoS ONE 2016, 11, e0166026. [CrossRef] [PubMed]

105. Brockow, K.; Grabenhorst, P.; Abeck, D.; Traupe, B.; Ring, J.; Hoppe, U.; Wolf, F. Effect of gentian violet, corticosteroid and tar preparations in Staphylococcus-aureus-colonized atopic eczema. Dermatology (Baselswitzerland) 1999, 199, 231-236. [CrossRef] [PubMed]

106. Huang, J.T.; Abrams, M.; Tlougan, B.; Rademaker, A.; Paller, A.S. Treatment of Staphylococcus aureus Colonization in Atopic Dermatitis Decreases Disease Severity. Pediatrics 2009, 123, e808-e814. [CrossRef] [PubMed]

107. Boguniewicz, M.; Sampson, H.; Leung, S.B.; Harbeck, R.; Leung, D.Y. Effects of cefuroxime axetil on Staphylococcus aureus colonization and superantigen production in atopic dermatitis. J. Allergy Clin. Immunol. 2001, 108, 651-652. [CrossRef] [PubMed]

108. Ewing, C.I.; Ashcroft, C.; Gibbs, A.C.; Jones, G.A.; Connor, P.J.; David, T.J. Flucloxacillin in the treatment of atopic dermatitis. Br. J. Dermatol. 1998, 138, 1022-1029. [CrossRef] [PubMed]

109. Gonzalez, M.E.; Schaffer, J.V.; Orlow, S.J.; Gao, Z.; Li, H.; Alekseyenko, A.V.; Blaser, M.J. Cutaneous microbiome effects of fluticasone propionate cream and adjunctive bleach baths in childhood atopic dermatitis. J. Am. Acad. Dermatol. 2016, 75, 481-493.e8. [CrossRef] [PubMed]

110. Seite, S.; Flores, G.E.; Henley, J.B.; Martin, R.; Zelenkova, H.; Aguilar, L.; Fierer, N. Microbiome of affected and unaffected skin of patients with atopic dermatitis before and after emollient treatment. J. Drugs Dermatol. 2014, 13, 1365-1372. [PubMed] 
111. Pelucchi, C.; Chatenoud, L.; Turati, F.; Galeone, C.; Moja, L.; Bach, J.F.; La Vecchia, C. Probiotics supplementation during pregnancy or infancy for the prevention of atopic dermatitis: A meta-analysis. Epidemiology (Camb. Mass.) 2012, 23, 402-414. [CrossRef] [PubMed]

112. Tan, J.; Berg, M. Rosacea: Current state of epidemiology. J. Am. Acad. Dermatol. 2013, 69, S27-S35. [CrossRef] [PubMed]

113. Wilkin, J.; Dahl, M.; Detmar, M.; Drake, L.; Feinstein, A.; Odom, R.; Powell, F. Standard classification of rosacea: Report of the National Rosacea Society Expert Committee on the Classification and Staging of Rosacea. J. Am. Acad. Dermatol. 2002, 46, 584-587. [CrossRef] [PubMed]

114. Two, A.M.; Wu, W.; Gallo, R.L.; Hata, T.R. Rosacea. J. Am. Acad. Dermatol. 2015, 72, 749-758. [CrossRef] [PubMed]

115. Jarmuda, S.; O’Reilly, N.; Zaba, R.; Jakubowicz, O.; Szkaradkiewicz, A.; Kavanagh, K. Potential role of Demodex mites and bacteria in the induction of rosacea. J. Med. Microbiol.. 2012, 61, 1504-1510. [CrossRef] [PubMed]

116. Zhao, Y.E.; Wu, L.P.; Peng, Y.; Cheng, H. Retrospective analysis of the association between Demodex infestation and rosacea. Arch. Dermatol. 2010, 146, 896-902. [CrossRef] [PubMed]

117. Casas, C.; Paul, C.; Lahfa, M.; Livideanu, B.; Lejeune, O.; Alvarez-Georges, S.; Saint-Martory, C.; Degouy, A.; Mengeaud, V.; Ginisty, H.; et al. Quantification of Demodex folliculorum by PCR in rosacea and its relationship to skin innate immune activation. Exp. Dermatol. 2012, 21, 906-910. [CrossRef] [PubMed]

118. Chang, Y.S.; Huang, Y.C. Role of Demodex mite infestation in rosacea: A systematic review and meta-analysis. J. Am. Acad. Dermatol. 2017, 77, 441-447.e6. [CrossRef] [PubMed]

119. Roihu, T.; Kariniemi, A.L. Demodex mites in acne rosacea. J. Cutan. Pathol. 1998, 25, 550-552. [CrossRef] [PubMed]

120. Koller, B.; Muller-Wiefel, A.S.; Rupec, R.; Korting, H.C.; Ruzicka, T. Chitin modulates innate immune responses of keratinocytes. PLoS ONE 2011, 6, e16594. [CrossRef] [PubMed]

121. Kocak, M.; Yagli, S.; Vahapoglu, G.; Eksioglu, M. Permethrin 5\% cream versus metronidazole $0.75 \%$ gel for the treatment of papulopustular rosacea. A randomized double-blind placebo-controlled study. Dermatology (Basel Switzerland) 2002, 205, 265-270. [CrossRef] [PubMed]

122. Lacey, N.; Delaney, S.; Kavanagh, K.; Powell, F.C. Mite-related bacterial antigens stimulate inflammatory cells in rosacea. Br. J. Dermatol. 2007, 157, 474-481. [CrossRef] [PubMed]

123. Szkaradkiewicz, A.; Chudzicka-Strugala, I.; Karpinski, T.M.; Goslinska-Pawlowska, O.; Tulecka, T.; Chudzicki, W.; Szkaradkiewicz, A.K.; Zaba, R. Bacillus oleronius and Demodex mite infestation in patients with chronic blepharitis. Clin. Microbiol.. Infect. 2012, 18, 1020-1025. [CrossRef] [PubMed]

124. O'Reilly, N.; Menezes, N.; Kavanagh, K. Positive correlation between serum immunoreactivity to Demodex-associated Bacillus proteins and erythematotelangiectatic rosacea. Br. J. Dermatol. 2012, 167, 1032-1036. [CrossRef] [PubMed]

125. Whitfeld, M.; Gunasingam, N.; Leow, L.J.; Shirato, K.; Preda, V. Staphylococcus epidermidis: A possible role in the pustules of rosacea. J. Am. Acad. Dermatol. 2011, 64, 49-52. [CrossRef] [PubMed]

126. Dahl, M.V.; Ross, A.J.; Schlievert, P.M. Temperature regulates bacterial protein production: Possible role in rosacea. J. Am. Acad. Dermatol. 2004, 50, 266-272. [CrossRef] [PubMed]

127. Nam, J.H.; Yun, Y.; Kim, H.S.; Kim, H.N.; Jung, H.J.; Chang, Y.; Ryu, S.; Shin, H.; Kim, H.L.; Kim, W.S. Rosacea and its association with enteral microbiota in Korean females. Exp. Dermatol. 2017. [CrossRef] [PubMed]

128. Brown, L.M. Helicobacter pylori: Epidemiology and routes of transmission. Epidemiol. Rev. 2000, 22, $283-297$. [CrossRef] [PubMed]

129. Holmes, A.D. Potential role of microorganisms in the pathogenesis of rosacea. J. Am. Acad. Dermatol. 2013, 69, 1025-1032. [CrossRef] [PubMed]

130. Bhattarai, S.; Agrawal, A.; Rijal, A.; Majhi, S.; Pradhan, B.; Dhakal, S.S. The study of prevalence of Helicobacter pylori in patients with acne rosacea. Kathmandu Univ. Med. J. 2012, 10, 49-52. [CrossRef]

131. Zandi, S.; Shamsadini, S.; Zahedi, M.J.; Hyatbaksh, M. Helicobacter pylori and rosacea. Eastern Mediterranean health journal $=$ La revue de sante de la Mediterranee orientale $=$ al-Majallah al-sihhiyah li-sharq al-mutawassit. East. Mediterr. Health J. 2003, 9, 167-171. [PubMed]

132. Pakodi, F.; Abdel-Salam, O.M.; Debreceni, A.; Mozsik, G. Helicobacter pylori. One bacterium and a broad spectrum of human disease! An overview. J. Physiol. Paris 2000, 94, 139-152. [CrossRef]

133. Lazaridou, E.; Apalla, Z.; Sotiraki, S.; Ziakas, N.G.; Fotiadou, C.; Ioannides, D. Clinical and laboratory study of rosacea in northern Greece. J. Eur. Acad. Dermatol. Venereol. 2010, 24, 410-414. [CrossRef] [PubMed] 
134. Bonamigo, R.R.; Leite, C.S.; Wagner, M.; Bakos, L. Rosacea and Helicobacter pylori: Interference of systemic antibiotic in the study of possible association. J. Eur. Acad. Dermatol. Venereol. 2000, 14, 424-425. [CrossRef] [PubMed]

135. Utas, S.; Ozbakir, O.; Turasan, A.; Utas, C. Helicobacter pylori eradication treatment reduces the severity of rosacea. J. Am. Acad. Dermatol. 1999, 40, 433-435. [CrossRef]

136. Szlachcic, A. The link between Helicobacter pylori infection and rosacea. J. Eur. Acad. Dermatol. Venereol. 2002, 16, 328-333. [CrossRef] [PubMed]

137. Boixeda de Miquel, D.; Vazquez Romero, M.; Vazquez Sequeiros, E.; Foruny Olcina, J.R.; Boixeda de Miquel, P.; Lopez San Roman, A.; Aleman Villanueva, S.; Martin de Argila de Prados, C. Effect of Helicobacter pylori eradication therapy in rosacea patients. Rev. Esp. Enferm. Dig. 2006, 98, 501-509. [CrossRef] [PubMed]

138. Argenziano, G.; Donnarumma, G.; Iovene, M.R.; Arnese, P.; Baldassarre, M.A.; Baroni, A. Incidence of anti-Helicobacter pylori and anti-CagA antibodies in rosacea patients. Int. J. Dermatol. 2003, 42, 601-604. [CrossRef] [PubMed]

139. Szlachcic, A.; Sliwowski, Z.; Karczewska, E.; Bielanski, W.; Pytko-Polonczyk, J.; Konturek, S.J. Helicobacter pylori and its eradication in rosacea. J. Physiol. Pharmacol. 1999, 50, 777-786. [PubMed]

140. Sharma, V.K.; Lynn, A.; Kaminski, M.; Vasudeva, R.; Howden, C.W. A study of the prevalence of Helicobacter pylori infection and other markers of upper gastrointestinal tract disease in patients with rosacea. Am. J. Gastroenterol. 1998, 93, 220-222. [CrossRef] [PubMed]

141. Son, S.W.; Kim, I.H.; Oh, C.H.; Kim, J.G. The response of rosacea to eradication of Helicobacter pylori. Br. J. Dermatol. 1999, 140, 984-985. [CrossRef] [PubMed]

142. Jorgensen, A.R.; Egeberg, A.; Gideonsson, R.; Weinstock, L.B.; Thyssen, E.P.; Thyssen, J.P. Rosacea is associated with Helicobacter pylori: A systematic review and meta-analysis. J. Eur. Acad. Dermatol. Venereol. 2017, 31, 2010-2015. [CrossRef] [PubMed]

143. Pariser, D.M.; Bagel, J.; Gelfand, J.M.; Korman, N.J.; Ritchlin, C.T.; Strober, B.E.; Van Voorhees, A.S.; Young, M.; Rittenberg, S.; Lebwohl, M.G.; et al. National Psoriasis Foundation clinical consensus on disease severity. Arch. Dermatol. 2007, 143, 239-242. [CrossRef] [PubMed]

144. Schon, M.P.; Boehncke, W.H. Psoriasis. N. Engl. J. Med. 2005, 352, 1899-1912. [CrossRef] [PubMed]

145. Xu, X.; Zhang, H.Y. The Immunogenetics of Psoriasis and Implications for Drug Repositioning. Int. J. Mol. Sci. 2017, 18, 2650. [CrossRef]

146. Gao, Z.; Tseng, C.H.; Strober, B.E.; Pei, Z.; Blaser, M.J. Substantial alterations of the cutaneous bacterial biota in psoriatic lesions. PLoS ONE 2008, 3, e2719. [CrossRef] [PubMed]

147. Assarsson, M.; Duvetorp, A.; Dienus, O.; Soderman, J.; Seifert, O. Significant Changes in the Skin Microbiome in Patients with Chronic Plaque Psoriasis after Treatment with Narrowband Ultraviolet B. Acta Dermatol. Venereol. 2018, 98, 428-436. [CrossRef] [PubMed]

148. Alekseyenko, A.V.; Perez-Perez, G.I.; De Souza, A.; Strober, B.; Gao, Z.; Bihan, M.; Li, K.; Methe, B.A.; Blaser, M.J. Community differentiation of the cutaneous microbiota in psoriasis. Microbiome 2013, 1, 31. [CrossRef] [PubMed]

149. Ng, C.Y.; Huang, Y.H.; Chu, C.F.; Wu, T.C.; Liu, S.H. Risks for Staphylococcus aureus colonization in patients with psoriasis: A systematic review and meta-analysis. Br. J. Dermatol. 2017, 177, 967-977. [CrossRef] [PubMed]

150. Chang, H.W.; Yan, D.; Singh, R.; Liu, J.; Lu, X.; Ucmak, D.; Lee, K.; Afifi, L.; Fadrosh, D.; Leech, J.; et al. Alteration of the cutaneous microbiome in psoriasis and potential role in Th17 polarization. Microbiome 2018, 6, 154. [CrossRef] [PubMed]

151. Martin, R.; Henley, J.B.; Sarrazin, P.; Seite, S. Skin Microbiome in Patients With Psoriasis Before and After Balneotherapy at the Thermal Care Center of La Roche-Posay. J. Drugs Dermatol. 2015, 14, 1400-1405. [PubMed]

152. Tan, L.; Zhao, S.; Zhu, W.; Wu, L.; Li, J.; Shen, M.; Lei, L.; Chen, X.; Peng, C. The Akkermansia muciniphila is a gut microbiota signature in psoriasis. Exp. Dermatol. 2018, 27, 144-149. [CrossRef] [PubMed]

153. Li, J.; Lin, S.; Vanhoutte, P.M.; Woo, C.W.; Xu, A. Akkermansia Muciniphila Protects Against Atherosclerosis by Preventing Metabolic Endotoxemia-Induced Inflammation in Apoe-/- Mice. Circulation 2016, 133, 2434-2446. [CrossRef] [PubMed]

154. Schneeberger, M.; Everard, A.; Gomez-Valades, A.G.; Matamoros, S.; Ramirez, S.; Delzenne, N.M.; Gomis, R.; Claret, M.; Cani, P.D. Akkermansia muciniphila inversely correlates with the onset of inflammation, altered adipose tissue metabolism and metabolic disorders during obesity in mice. Sci. Rep. 2015, 5, 16643. [CrossRef] [PubMed] 
155. Png, C.W.; Linden, S.K.; Gilshenan, K.S.; Zoetendal, E.G.; McSweeney, C.S.; Sly, L.I.; McGuckin, M.A.; Florin, T.H. Mucolytic bacteria with increased prevalence in IBD mucosa augment in vitro utilization of mucin by other bacteria. Am. J. Gastroenterol. 2010, 105, 2420-2428. [CrossRef] [PubMed]

156. Reunanen, J.; Kainulainen, V.; Huuskonen, L.; Ottman, N.; Belzer, C.; Huhtinen, H.; de Vos, W.M.; Satokari, R. Akkermansia muciniphila Adheres to Enterocytes and Strengthens the Integrity of the Epithelial Cell Layer. Appl. Env. Microbiol. 2015, 81, 3655-3662. [CrossRef] [PubMed]

157. Scher, J.U.; Ubeda, C.; Artacho, A.; Attur, M.; Isaac, S.; Reddy, S.M.; Marmon, S.; Neimann, A.; Brusca, S.; Patel, T.; et al. Decreased bacterial diversity characterizes the altered gut microbiota in patients with psoriatic arthritis, resembling dysbiosis in inflammatory bowel disease. Arthritis Rheumatol. 2015, 67, 128-139. [CrossRef] [PubMed]

158. Masallat, D.; Moemen, D.; State, A.F. Gut bacterial microbiota in psoriasis: A case control study. Afr. J. Microbiol. Res. 2016, 10, 1337-1343. [CrossRef]

159. Benhadou, F.; Mintoff, D.; Schnebert, B.; Thio, H.B. Psoriasis and Microbiota: A Systematic Review. Diseases 2018, 6, 47. [CrossRef] [PubMed]

160. Boulange, C.L.; Neves, A.L.; Chilloux, J.; Nicholson, J.K.; Dumas, M.E. Impact of the gut microbiota on inflammation, obesity, and metabolic disease. Genome Med. 2016, 8, 42. [CrossRef] [PubMed]

161. Codoñer, F.M.; Ramírez-Bosca, A.; Climent, E.; Carrión-Gutierrez, M.; Guerrero, M.; Pérez-Orquín, J.M.; Horga de la Parte, J.; Genovés, S.; Ramón, D.; Navarro-López, V.; et al. Gut microbial composition in patients with psoriasis. Sci. Rep. 2018, 8, 3812. [CrossRef] [PubMed]

162. Zakostelska, Z.; Malkova, J.; Klimesova, K.; Rossmann, P.; Hornova, M.; Novosadova, I.; Stehlikova, Z.; Kostovcik, M.; Hudcovic, T.; Stepankova, R.; et al. Intestinal Microbiota Promotes Psoriasis-Like Skin Inflammation by Enhancing Th17 Response. PLoS ONE 2016, 11, e0159539. [CrossRef] [PubMed]

163. An, Q.; Sun, M.; Qi, R.Q.; Zhang, L.; Zhai, J.L.; Hong, Y.X.; Song, B.; Chen, H.D.; Gao, X.H. High Staphylococcus epidermidis Colonization and Impaired Permeability Barrier in Facial Seborrheic Dermatitis. Chin. Med. J. 2017, 130, 1662-1669. [CrossRef] [PubMed]

164. Berg, M. Epidemiological studies of the influence of sunlight on the skin. Photodermatol 1989, 6, 80-84. [PubMed]

165. Gary, G. Optimizing treatment approaches in seborrheic dermatitis. J. Clin. Aesthet. Dermatol. 2013, 6, 44-49. [PubMed]

166. Paulino, L.C. New perspectives on dandruff and seborrheic dermatitis: Lessons we learned from bacterial and fungal skin microbiota. Eur. J. Dermatol. 2017, 27, 4-7. [CrossRef] [PubMed]

167. Tanaka, A.; Cho, O.; Saito, C.; Saito, M.; Tsuboi, R.; Sugita, T. Comprehensive pyrosequencing analysis of the bacterial microbiota of the skin of patients with seborrheic dermatitis. Microbiol. Immunol. 2016, 60, 521-526. [CrossRef] [PubMed]

168. Hill, C.; Guarner, F.; Reid, G.; Gibson, G.R.; Merenstein, D.J.; Pot, B.; Morelli, L.; Canani, R.B.; Flint, H.J.; Salminen, S.; et al. Expert consensus document. The International Scientific Association for Probiotics and Prebiotics consensus statement on the scope and appropriate use of the term probiotic. Nat. Rev. Gastroenterol. Hepatol. 2014, 11, 506-514. [CrossRef] [PubMed]

169. Kechagia, M.; Basoulis, D.; Konstantopoulou, S.; Dimitriadi, D.; Gyftopoulou, K.; Skarmoutsou, N.; Fakiri, E.M. Health benefits of probiotics: A review. ISRN Nutr. 2013, 2013, 481651. [CrossRef] [PubMed]

170. Fuchs-Tarlovsky, V.; Marquez-Barba, M.F.; Sriram, K. Probiotics in dermatologic practice. Nutrition 2016, 32, 289-295. [CrossRef] [PubMed]

171. Gourbeyre, P.; Denery, S.; Bodinier, M. Probiotics, prebiotics, and synbiotics: Impact on the gut immune system and allergic reactions. J. Leukoc. Biol. 2011, 89, 685-695. [CrossRef] [PubMed]

172. Huang, R.; Ning, H.; Shen, M.; Li, J.; Zhang, J.; Chen, X. Probiotics for the Treatment of Atopic Dermatitis in Children: A Systematic Review and Meta-Analysis of Randomized Controlled Trials. Front. Cell Infect. Microbiol. 2017, 7, 392. [CrossRef] [PubMed]

173. Lee, J.; Seto, D.; Bielory, L. Meta-analysis of clinical trials of probiotics for prevention and treatment of pediatric atopic dermatitis. J. Allergy Clin. Immunol. 2008, 121, 116-121.e111. [CrossRef] [PubMed]

174. Doege, K.; Grajecki, D.; Zyriax, B.C.; Detinkina, E.; Zu Eulenburg, C.; Buhling, K.J. Impact of maternal supplementation with probiotics during pregnancy on atopic eczema in childhood-A meta-analysis. Br. J. Nutr. 2012, 107, 1-6. [CrossRef] [PubMed]

175. Vijayashankar, M. Pustular Psoriasis Responding to Probiotics-A New Insight. Nasza Dermatol. Online 2012, 3, 326-328. [CrossRef] 
176. Jenks, K.; Stebbings, S.; Burton, J.; Schultz, M.; Herbison, P.; Highton, J. Probiotic therapy for the treatment of spondyloarthritis: A randomized controlled trial. J. Rheumatol. 2010, 37, 2118-2125. [CrossRef] [PubMed]

177. Notay, M.; Foolad, N.; Vaughn, A.R.; Sivamani, R.K. Probiotics, Prebiotics, and Synbiotics for the Treatment and Prevention of Adult Dermatological Diseases. Am. J. Clin. Dermatol. 2017, 18, 721-732. [CrossRef] [PubMed]

178. Stokes, J.H.; Pillsbury, D.M. The effect on the skin of emotional and nervous states: III. Theoretical and practical consideration of a gastro-intestinal mechanism. JAMA Dermatol. 1930, 22, 962-993. [CrossRef]

179. Arck, P.; Handjiski, B.; Hagen, E.; Pincus, M.; Bruenahl, C.; Bienenstock, J.; Paus, R. Is there a 'gut-brain-skin axis'? Exp. Dermatol. 2010, 19, 401-405. [CrossRef] [PubMed]

180. Rea, K.; Dinan, T.G.; Cryan, J.F. The microbiome: A key regulator of stress and neuroinflammation. Neurobiol. Stress 2016, 4, 23-33. [CrossRef] [PubMed]

181. Cani, P.D.; Amar, J.; Iglesias, M.A.; Poggi, M.; Knauf, C.; Bastelica, D.; Neyrinck, A.M.; Fava, F.; Tuohy, K.M.; Chabo, C.; et al. Metabolic Endotoxemia Initiates Obesity and Insulin Resistance. Diabetes 2007, 56, 1761. [CrossRef] [PubMed]

182. Ramirez-Bosca, A.; Navarro-Lopez, V.; Martinez-Andres, A.; Such, J.; Frances, R.; Horga de la Parte, J.; Asin-Llorca, M. Identification of Bacterial DNA in the Peripheral Blood of Patients With Active Psoriasis. JAMA Dermatol. 2015, 151, 670-671. [CrossRef] [PubMed]

(C) 2019 by the authors. Licensee MDPI, Basel, Switzerland. This article is an open access article distributed under the terms and conditions of the Creative Commons Attribution (CC BY) license (http://creativecommons.org/licenses/by/4.0/). 